\title{
MARYJA - NASZA SIOSTRA Patrystyczny przyczynek do mariologii antropologicznej
}

W nauczaniu Ojców Kościoła Maryja zajmowała ważne miejsce. Elementy mariologii obecne są w dziełach najwcześniejszych Ojców np. u Ignacego z Antiochii, który pisze o dziewictwie i macierzyństwie Maryi ${ }^{1}$. Jako uzasadnioną należy uznać opinię, że Ojcowie Kościoła swoją refleksję mariologiczną umieszczali w kontekście historii zbawienia, odnosząc do niej postać Maryi. Prowadzi to w konsekwencji do nadania mariologii rysu zdecydowanie chrystocentrycznego. Stąd też - jak wiadomo - zasadniczą tematykę mariologii patrystycznej stanowi paralela Ewa - Maryja (począwszy od Justyna ${ }^{2}$ ) oraz dziewictwo i macierzyństwo Maryi. Nietrudno zauważyé, że tak ujęta tematyka pozostaje w bezpośrednim związku z Osobą i dziełem Chrystusa. Daje to podstawę do przyjęcia wniosku, że Ojcowie Kościoła nie podejmują refleksji nad Maryją bez równoczesnego ukazania Jej związku z Chrystusem. W tej grupie osobne miejsce zajmuje problematyka Boskiego Macierzyństwa Maryi i przysługującego Jej z tej racji tytułu Qeotkoj. W przekazach patrystycznych występuje on na długo przed Soborem Efeskim. Ukształtował się w nurcie rozważań na temat dziewictwa i macierzyństwa Maryi.

Nieco później mariologia patrystyczna ubogacona zostaje wątkiem związku Maryi z Kościołem (Maria - typus Ecclesiae) ${ }^{3}$. Stanowi on rozwinięcie i uszczegółowienie paraleli Ewa - Maryja i wpisuje się w całość doktryny mariologicznej Ojców Kościoła. O wiele skromniejsze miejsce w nauczaniu Ojców zajmuje ukazanie relacji Maryi z Ojcem, a także z Duchem Świętym.

Wydaje się, że tak ujęta mariologia patrystyczna nie oddaje jednak w pełni bogactwa przemyśleń Ojców Kościoła na temat Matki Zbawiciela. Wysuwa się w niej bowiem na plan pierwszy kierunek, który we współczesnej mariologii określany jest jako wertykalny (odniesienie do Osób Boskich, zwłaszcza do Chrystusa i dzieła Odkupienia), mało widoczny jest zaś kierunek horyzontalny

\footnotetext{
${ }^{1}$ Por. Ignatius Antiochenus, Epistula ad Ephesios 19, 1.

2 Por. Iustinus, Dialogus cum Judaeo Tryphone 100, 4-5.

${ }^{3}$ Por. Ambrosius, Expositio Evangelii secundum Lucam 2, 7.
} 
- odniesienie do człowieka ${ }^{4}$. Tymczasem związek Maryi z Chrystusem i dziełem Odkupienia nie oddziela Jej od ludzi. To przekonanie jest głęboko zakorzenione w świadomości Ojców Kościoła chociaż nie zawsze dostrzegane przez współczesnych teologów.

Jednym z przykładów kierunku horyzontalnego w mariologii Ojców jest nazwanie Maryi naszą Siostrą. Uczynił to jako pierwszy Atanazy Wielki w Liście do Epikteta ${ }^{5}$. Dostosowując się do podziału, którym posługuje się współczesna mariologia, określiliśmy (w tytule) to wyrażenie Atanazego jako przyczynek do mariologii antropologicznej. Wprawdzie - jak się wydaje obecnie mariologowie używają zamiennie pojęć mariologia antropologiczna i antropologia mariologiczna ${ }^{6}$, to jednak słuszne byłoby tutaj wprowadzenie rozróżnienia. Jak potwierdzają liczne opracowania, antropologia mariologiczna pozostaje w ścisłym związku z teologią feministyczną, ukazując (w oparciu o Maryję) rolę kobiety w Kościele i świecie. Przedmiotem natomiast mariologii antropologicznej winno być ukazanie związku Maryi z wszystkimi ludźmi, pozostawanie z nimi w jednym szeregu, mimo przywileju Boskiego Macierzyństwa. W tym ujęciu na plan pierwszy wysuwa się przybliżenie tego, co Matkę Bożą łączy z ludźmi i decyduje o tym, że pozostaje ona nadal - mimo wniebowzięcia - jedną z nas ${ }^{7}$. W takim też sensie wyrażenie Atanazego przywołuje adhortacja apostolska Marialis cultus stwierdzając: „Maryja bowiem przynależy do naszego rodzaju, jest prawdziwą Córką Ewy, chociaż nie znającą zmazy tejże matki; jest prawdziwą Si ostrą naszą, która wiodąc życie ziemskie w pokorze i ubóstwie w pełni podzieliła nasz los"s.

Tekst, którym Atanazy nazwał Maryję naszą siostrą, brzmi następująco:

."To, co się narodziło z Maryi, jak świadczy Pismo Święte, z natury było prawdziwym człowiekiem, prawdziwe również było ciało Jezusa, ponieważ było takie

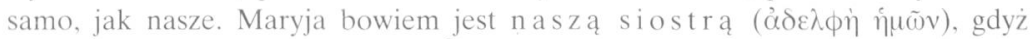
wszyscy jesteśmy dziećmi Adama"9".

${ }^{4}$ Por. B. Ferdek, Nasza siostra - córą i Matką Pana. Mariologia jako przestrzeń syntezy dogmatyki, Swidnica 2007, 12.

5 Athanasius Alexandrinus, Epistula ad Epictetum 7, PG 26, $1061 \mathrm{~B}$.

${ }^{6}$ Por. np. podział bibliografii w: R. Laurentin, Matka Pana, tłum. Z. Proczek, Warszawa 1989, 328-329; 352-353.

7 Por. T. Špidlík, Per una mariologia antropologica, „Marianum” 41 (1979) 491-506.

${ }^{8}$ Paulus VI, Adhortatio Apostolica „Marialis cultus” 56. Wprowadzeniem do tego wniosku jest znajdujące się wcześniej stwierdzenie: „[...] Jej nieustanne i skuteczne wstawiennictwo, mocą którego - chociaż wzięta do nieba - jest jak najbliżej wiernych Ją wzywających".

9 Epistula ad Epictetum 7, PG 26, 1061B, tłum. pol. LG I (wyd. 1) Poznań 1982, 429 (lub wyd. 2, Poznań 2006, 431). Tłumaczenie tego fragmentu podaje także F. Courth (Mariologia, tłum. W. Szymona, Poznań 2005, 68) w brzmieniu następującym: „A zatem ludzkie co do natury i prawdziwe było ciało Zbawiciela, wzięte z Maryi wedle Bożych Pism. Prawdziwe zaś było, gdyz było takie samo, jak nasze, bowiem Maryja jest naszą siostrą, a wszyscy stanowimy potomstwo Adama". 
Nietrudno zauważyć, że kontekst, w którym Atanazy umieścił analizowane przez nas wyrażenie jest jednoznacznie chrystologiczny. Biskup Aleksandrii stara się na pierwszym miejscu dowieść prawdziwości ciała ludzkiego Chrystusa. Podkreśla, że narodzenie Chrystusa z Maryi oznacza, iż ,,[... Syn Boży z natury i istoty [...] ciało swe wziął ze świętej Maryi" "10. Realność człowieczeństwa Syna Bożego wynika zatem z faktu, że Maryja była w pełnym tego słowa znaczeniu człowiekiem. Zrodzony z Niej Zbawiciel posiada takie ciało, jak Ona, czyli takie ciało, jakie posiadają wszyscy ludzie. Takie rozumowanie nie przesłania Atanazemu skutków Wcielenia dla ludzi. Z naciskiem głosi:

„Słowo przyjęło w pełni naszą naturę i ją złożyło w ofierze, a nam dało udział w swej boskiej naturze"11.

Swoją uwagę jednak koncentruje na argumentach biblijnych, które potwierdzają prawdziwość narodzenia się Chrystusa z Maryi. Jego zdaniem, już Izajasz przepowiedział Maryję słowami „oto Panna” (Iz 7,14), a Gabriel został posłany do „dziewicy poślubionej mężowi” (Łk 1,27), aby przez tę wzmiankę o poślubieniu podkreślić, że Maryja prawdziwie jest człowiekiem. Jako kolejny argument za prawdziwością narodzin Syna Bożego w ludzkim ciele Atanazy wylicza słowa Łk 2, 7: „zawinęła [Go] w pieluszki” oraz Łk 11, 27: „,błogosławione piersi, któreś ssał”. Zwraca uwagę także na formę słowną, którą posługuje się Gabriel przy zwiastowaniu: nie mówi o zrodzonym „w żłobie”, ale o zrodzonym ,z Ciebie” ('̇x ooṽ), aby podkreślić, że Jezus narodzi się z Niej jako prawdziwy i pełny człowiek, ,,aby uwierzono, że to Dziecię prawdziwie z Niej się poczęło i narodziło" 12 .

Jak łatwo dostrzec, powyższa argumentacja ma zastosowanie zarówno dla wykazania prawdziwości narodzin i ludzkiego ciała Chrystusa, jak również dla wykazania realności macierzyństwa Maryi. Wywód Atanazego zatem posiada równocześnie charakter chrystologiczny i mariologiczny. Jego mariologia raczej nie rozwija się osobno, lecz stanowi integralną część nauki o Wcieleniu. Tym niemniej możemy mówić o doktrynie mariologicznej u Biskupa Aleksandrii. Jest ona niestety stosunkowo mało opracowana, zwłaszcza na gruncie języka polskiego. Za pozytywne w tym temacie należy uznać syntetyczne studium M. Starowieyskiego ${ }^{13}$ poszerzone o opracowanie J. Królikowskiego $^{14}$. Encyklopedyczne opracowania obcojęzyczne także nie podają sys-

${ }^{10}$ Epistula ad Epictetum 2, PG 26, $1052 \mathrm{C}$.

11 Tamże 6, PG 26, 1060C.

12 Tamże 5, PG 26, 1057C.

13 Por. M. Starowieyski, Mariologia św. Atanazego Wielkiego, RTK 23 (1976) z. 4, 109-132.

${ }^{14}$ Por. J. Królikowski, Theotokos $w$ teologii św. Atanazego. Przełom mariologiczny w IV wieku i jego znaczenie, SMa 2 (2000) nr 1, 56-73. 
tematycznego wykładu mariologii Atanazego ${ }^{15}$. Autorzy zajmujący się mariologią tego Ojca Kościoła wskazują zgodnie na jej wymiar chrystologiczny. Wymiar antropologiczny jest raczej mało dostrzegany. Zwraca się głównie uwagę na to, że Biskup Aleksandrii swoją naukę koncentruje na Osobie Chrystusa; Maryja ma w niej drugoplanowe miejsce. Pewną trudność stanowi rozgraniczenie argumentacji Atanazego za prawdziwym człowieczeństwem Chrystusa (w której jest miejsce dla teologii maryjnej) od argumentacji za bóstwem Chrystusa. Należy zgodzić się z tezą, że większość swoich traktatów Doktor Aleksandryjski poświęca - zgodnie z uwarunkowaniami epoki, w której żyje - obronie bóstwa Chrystusa i Jego współistotności Ojcu. Nie sprzyja to jednak wydobyciu na światło dzienne wszystkich elementów jego mariologii. M. Starowieyski przytacza wprawdzie interesujące nas wyrażenie Atanazego ,nasza siostra”, ale umieszcza je w kontekście jego nauczania na temat Boskiego Macierzyństwa Maryi ${ }^{16}$. Ujęcie takie jest zgodne z przyjęciem nurtu chrystologicznego mariologii Biskupa Aleksandrii. Wydaje się jednak, że nie wydobywa do końca bogactwa treści, zawartej w powyższym zwrocie. Istotnie, Atanazy uporczywie podkreśla, że Maryja jest człowiekiem, aby przede wszystkim wykazać, że Słowo, które z Niej przyjęło ciało, jest także prawdziwie człowiekiem - takim jak my ${ }^{17}$. Wydaje się, że dochodzi tu do głosu schemat chrystologii aleksandryjskiej, która opowiadała się za połącze-

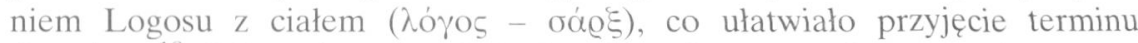

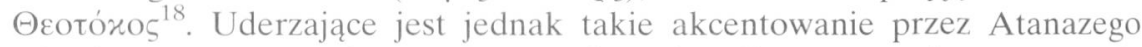
człowieczeństwa Maryi. Wyrażone to jest nie tylko w omawianym zwrocie „nasza siostra", ale na uwagę zasługuje także jego objaśnienie, które zostaje dołączone do tego tytułu: „Gdyż w s z y s c y jesteśmy dziećmi (potomstwem) Adama" ${ }^{19}$. Wyrażona jest w nim wyraźnie myśl o wspólnocie natury łączącej Maryję z ludźmi. Nieuzasadniona jest w tym kontekście obawa, że podkreślanie przez Atanazego człowieczeństwa Maryi mogłoby być rozumiane jako chęć poniżenia Jej ${ }^{20}$. Ojciec Kościoła wyraża bowiem w taki sposób zarówno

15 Por. G. Göl, Mariologie, HDG III/4, Freiburg - Wien 1978; A. Grimmler, Jesus Christus im Glauben der Kirche, I, Freiburg - Basel - Wien 1979. Na uwagę zasługuje również I. Ortiz de Urbina, Mariologia w patrystyce Wschodu, tłum. K. Obrycki, „Częstochowskie Studia Teologiczne" 6 (1978) 65-104 oraz D. Fernandez, Aktualność i wartość mariologii Ojców Kościoła, tamże 11 (1983) 73-91. Wśród autorów polskich przekrój mariologii patrystycznej podają: E. Florkowski, Matka Boża w nauce Ojców Kościoła, w: Gratia plena, Poznań 1975, 59-77 oraz J. Królikowski, Maryja w pamięci Kościota. Mariologia, cz. 1, Tarnów 1999. Na osobne wyszczególnienie zasługuje także seria Beatam me dicent, wydawana w Niepokalanowie od 1981 roku pod redakcją O.S.C. Napiórkowskiego.

${ }^{16}$ Por. Starowieyski, Mariologia św. Atanazego Wielkiego, s. 120-121.

17 Por. Athanasius Alexandrinus, Epistula ad Maximum 2, PG 26, 1088 B.

18 Por. Starowieyski, Mariologia św. Atanazego Wielkiego, s. 124

19 Athanasius, Epistula ad Epictetum 7, PG 26, $1061 \mathrm{~B}$.

20 Por. Starowieyski, Mariologia św. Atanazego Wielkiego, s. 121. 
więź Maryi z Chrystusem, jak i z ludźmi: jest Ona człowiekiem, naszą Siostrą i zarazem Matką Boga. Dzięki temu jest pośredniczką między czasem grzechu i czasem odkupienia, który Atanazy nazywa „czasami ostatecznymi” lub „wypełnieniem czasów”21.

Dla przybliżenia wymiaru antropologicznego mariologii Atanazego warto postawić pytanie o genezę Listu do Epikteta. List ten stanowi odpowiedź na pytanie, które Epiktet, biskup Koryntu, skierował do Biskupa Aleksandrii na temat opinii, które krążyły w gminie korynckiej. Według jednej z nich Chrystus posiadał ciało niecierpiętliwe, przyniesione z nieba i współistotne z Jego boskością. W tej sytuacji macierzyństwo Maryi byłoby pozbawione sensu. Wydaje się, że opinia taka mogła być echem apolinaryzmu. Druga z opinii z kolei powoływała się na pogląd, że Słowo tylko zamieszkało w Chrystusie, podobnie jak zamieszkiwało w prorokach i świętych. Nie było więc narodzin Chrystusa z Maryi, co pozbawiało Ją tytułu @eotóxos. W odpowiedzi Atanazy z całą stanowczością broni człowieczeństwa Syna Bożego, jak i człowieczeństwa Jego Matki, pisząc:

„Ojcowie, którzy zebrali się w Nicei nie twierdzili bynajmniej, że ciało, lecz że Syn jest współistotny Ojcu, i że Syn jest z substancji Ojca i oświadczyli również, że ciało pochodzi z Maryi według Pisma. Jeżeli Słowo jest współistotne ciału, to próżne jest

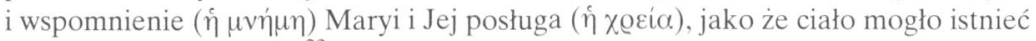
wiecznie przed Maryją",22.

J. Królikowski zwraca uwagę na występujący w tekście termin „wspomnienie Maryi". Jego zdaniem, greckie $\mu \nu \eta$ $\mu \eta$ jest nie tylko zwyczajnym wspomnieniem, ale także posiada znaczenie techniczne, właściwe dla języka liturgicznego, jak wspomnienie męczenników i świętych ${ }^{23}$. Prowadzi to do kolejnego pytania, czy Atanazy miał na myśli konkretne święto maryjne? Zdaniem J. Królikowskiego, jest to możliwe zwłaszcza dlatego, że kult odgrywał ważną rolę w myśleniu Atanazego ${ }^{24}$. Potwierdzenie tego można znaleźć w zakończeniu Listu do Epikteta, w którym Biskup Aleksandrii uznaje kult w Kościele za „[...] wyznanie wiary - zarówno pobożnie, jak i prawdziwie"25.

W kontekście powyższych rozważań słuszny wydaje się wniosek, że mariologia Atanazego, a zwłaszcza jej wymiar antropologiczny, ma związek z nawrotem doketyzmu w IV wieku, który kwestionował prawdziwość i integralność człowieczeństwa Chrystusa, a także realność Jego ludzkiego ciała. Należy przypuszczać, że była to także reakcja na herezję Ariusza, mająca na celu wy-

21 Por. Athanasius, Epistula ad Epictetum 12, PG 26, $1068 \mathrm{~B}$.

22 Tamże 4, PG 26, 1056-1057, cyt. za: Starowieyski, Mariologia św. Atanazego Wielkiego, s. 122.

${ }^{23}$ Por. Królikowski, Theotokos w teologii św. Atanazego, s. $63 \mathrm{nn}$.

24 Por. tamże, s. 64.

25 Athanasius, Epistula ad Epictetum 12, PG 26, 1069. 
eksponowanie Bóstwa Chrystusa. W tej sytuacji teologia Atanazego wypowiada się w doktrynie o prawdziwym i pełnym człowieczeństwie Chrystusa, wziętym z Maryi Dziewicy oraz o prawdziwym i pełnym człowieczeństwie Maryi, ponieważ przynależy Ona do rodzaju ludzkiego wywodzącego się od Adama: w takim to kontekście Maryja zostaje nazwana przez Biskupa Aleksandrii „naszą siostrą".

Czy jednak reakcja na doketyzm i związane z nią ukierunkowanie chrystologii było jedynym powodem, dla którego Atanazy tak uwypuklił człowieczeństwo Maryi i Jej związek z wszystkimi ludźmi? Wydaje się, że nasz Ojciec Kościoła mógł być także powodowany innym błędem, który plasował Maryję na pozycjach przeciwstawnych ludziom i był nadużyciem religijnym: chodzi o wspomnianych przez Epifaniusza kollyrydianek, które czciły Maryję jako boginię $^{26}$. Pisząc o nich biskup Salaminy był poruszony tymi praktykami i nakreślił jasne kryteria czci maryjnej ${ }^{27}$. Jest niewykluczone, że Atanazy słyszał o tym błędzie, tym bardziej, że przez Aleksandrię jako miasto portowe przewijali się z pewnością także podróżujący z Arabii. Mariologia antropologiczna Atanazego wraz z wyrażeniem ,nasza siostra” byłaby wtedy nie tylko reakcją na błędy kollyrydianek, ale także wyraźną i czytelną korektą kultu maryjnego, zachowującą swoją aktualność po dzisiejsze czasy. Za przyjęciem

${ }^{26}$ O takiej możliwości wspomina także M. Starowieyski (Mariologia św. Atanazego Wielkiego, s. 121); zob. Epiphanius, Ancoratus XIII 8; Haereses 78, 23; 79, 1; F. Cocchini, Colliridiani, DPAC I 734; K. Kowalik, Kollyrydianki, EK IX 367-368.

27 Por. Epiphanius, Haereses 78, 23; 79, 1, PG 42, 736B, 740C-741 A, tłum. pol. W. Szymona, w: Courth, Mariologia, s. 77-78: ,Zdumieliśmy się, usłyszawszy z kolei rzecz inną. Znowu pewni ludzie bez rozeznania w sprawach, które dotyczą Najświętszej Dziewicy, zapragnęli wbrew Bogu rozpowszechniać swoją naukę, i starają się to czynić, jakby opanowani przez szaleństwo oraz obłęd. Powiadają bowiem, że jakieś nierządnice przyniosły tę czczą herezję do Arabii, dokąd przybyły z Tracji. W imię Dziewicy i dla Jej czci ofiarowują chleb, i w tym celu odbywają spotkanie. W imię Najświętszej Dziewicy, przekraczając wszelką miarę, próbują podejmować bezbożne i bluźniercze działanie. Bowiem kobiety składają w Jej imię uroczyste ofiary, co zaiste jest rzeczą bezbożną i zbrodniczą, i całkowicie obcą nauce Ducha Świętego. Przeciw czcicielkom chleba, składającym ofiary Maryi [...] Bowiem do uszu naszych doszło, że owa herezja na powrót rozpowszechniła się w Arabii, przyjęta z Tracji i Górnej Scytii. Mianowicie niektóre niewiasty w dniu dorocznego święta stroją wóz czy też tron czworoboczny, okrywszy go z wierzchu lnianym płótnem, i przez kilka dni wykładają chleb, ofiarując go w imię Maryi. Wszystkie przyjmują swój kawałek chleba”, oraz Haereses 78, 24; 79, 7, PG 42, 737, thum pol. W. Szymona, w: Courth, Mariologia, s. 78: „Nie ma potrzeby, aby czcić świętych ponad konieczną miarę, lecz należy oddawać cześć ich Panu. Niech zatem nastanie kres błędu ludzi zwiedzionych na manowce. Bowiem Maryja ani nie jest Bogiem, ani nie posiada ciała z nieba, lecz poczęte z męża i niewiasty. Została powołana do życia zgodnie z obietnicą, jak Izaak. Przeto niech nikt nie składa ofiar w Jej imieniu, albowiem gubi swą duszę. Niech z kolei nikt nie zachowuje się też zuchwale, znieważając świętą Dziewicę. Oby się to nie zdarzyło! Albowiem ani po zrodzeniu, ani przed zrodzeniem Zbawiciela [z nikim] nie połączyła się cieleśnie. Niech we czci będzie Maryja: niech będą zaś uwielbieni Ojciec i Syn, i Duch Święty; niech nikt natomiast nie ubóstwia Maryi. Choć Maryja była także najpiękniejsza, i święta, i chwalebna, mimo to nie należy Jej oddawać czci boskiej”. 
takiej hipotezy zdaje się przemawiać tekst Leoncjusza z Bizancjum, który także

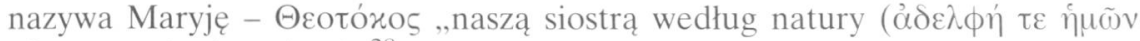

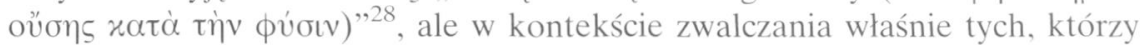
czczą Maryję jako boginię, nazywając ich filomarianitami ${ }^{29}$. Na uwagę zasługuje fakt, że poza Atanazym i Leoncjuszem z Bizancjum trudno jest odnaleźć w pismach innych Ojców Kościoła interesującego nas nazwania Maryi „naszą siostrą”. Występujące u Efrema sformułowanie: „Jestem dla Ciebie Siostrą z domu Dawida, który jest dla nas drugim Ojcem" wyraża raczej związek Maryi z Jezusem, a nie z ludźmi, co potwierdzają dalsze słowa: „I Matką Ci jestem, bo narodziłam Cię w łonie" ${ }^{30}$. Tak więc wyjątkowość formuły, którą posłużył się Atanazy, nasuwa wniosek, że chciał on poprzez jej użycie skierować na właściwe tory nie tylko dogmatyczne użycie mariologii, ale także pobożność maryjną i związany z nią kult Bogarodzicy. Mielibyśmy wtedy do czynienia $\mathrm{z}$ harmonijnym połączeniem lex credendi $\mathrm{z}$ lex orandi $\mathrm{w}$ przestrzeni mariologii.

Niewątpliwie kierunek interpretacji atanazjańskiego sformułowania Maryja - „nasza siostra” nadaje także wspomniana wyżej adhortacja apostolska Pawła VI Marialis cultus. Zawarty w niej zwrot ,jest prawdziwą Siostrą naszą" ${ }^{31}$, nie budzi wątpliwości co do zaczerpnięcia go z tekstu Listu do Epikteta, chociaż brakuje w tym miejscu adhortacji wyraźnego przypisu źródłowego z odniesieniem do tego listu. W świetle Marialis cultus stwierdzenie, że Maryja jest naszą Siostrą wskazuje na pierwszym miejscu, że przynależy Ona do naszego rodzaju, ponieważ jest córką Ewy, mimo, że wolna od zmazy grzechowej przez nią zaciągniętej. Atanazy sprowadził to do twierdzenia, że wszyscy jesteśmy dziećmi, czyli potomstwem Adama. Dzięki temu jest bliska każdemu człowiekowi, ponieważ związana jest z nami węzłem człowieczeństwa. Los człowieczy nie jest Jej obcy. Ona go podzieliła żyjąc w pokorze i ubóstwie, a także krocząc drogą boleści ${ }^{32}$. Wynika stąd skuteczność Jej wstawiennictwa, bo chociaż jest Wniebowzięta, to także teraz doskonale zna i rozumie problemy tych, którzy wzywają Jej pomocy. Czyni to prawdziwie po matczynemu, bo rzeczywiście jest naszą Matką. Skoro jednak jest również naszą Siostrą, to wynika z tego, iż jest także członkiem całego ludu Bożego, chociaż „przewyższającym inne”,33. Posiada bowiem szczególną godność jako Rodzi-

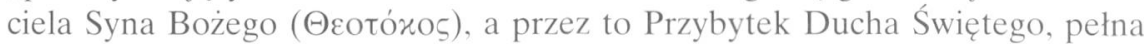

${ }^{28}$ Leontius Byzantinus, Contra nestorianos et eutychianos II, PG 86, 1325C.

29 Por. tamze III 6, PG 86, 1364B.

${ }^{30}$ Ephrem Syrus, Hymni de nativitate (Epiphania) 16, 10, ed. E. Beck, CSCO 187, Syr 83, s. 76. tłum. za Courth, Mariologia, s. 130: „Matką Twoją jest Ona i tylko Ona twoją też siostrą, razem z wszystkimi innymi. Stała się też matką, stała Twą siostrą".

31 Por. Adhortatio Apostolica ,Marialis cultus” 56; zob. wyżej nota 8.

32 Por. tamże.

33 Por. tamże. 
łaski i świętości, co daje Jej pozycję uprzywilejowaną wśród wszystkich innych stworzeń, zarówno ziemskich jak i niebieskich. Dlatego winna doznawać czci, wyrażanej modlitwami, chociaż może w większym stopniu powinny to być modlitwy dziękczynienia, niż prośby, zgodnie ze wskazaniami Ojców Kościoła, którzy dziękowali Bogu za Maryję, a Ją wysławiali za umożliwienie realizacji dzieła Odkupienia ${ }^{34}$. Szczególna relacja Maryi do Boga nie uszczupla jednak Jej człowieczeństwa. Maryja - nasza Siostra ukazuje Sobą, czym naprawdę jest człowieczeństwo. Wszak przywileje łaski Jej udzielone mają w pewien sposób charakter uprzedzający w stosunku do każdego człowieka. W Maryi - naszej Siostrze człowiek odnajduje nie tylko Towarzyszkę swoich bólów i cierpień, związanych z ziemskim pielgrzymowaniem, ale także pierwowzór człowieczeństwa w swoim punkcie wyjścia i dojścia ${ }^{35}$.

Przechodząc do konkluzji należy zauważyć, że oryginalność mariologii Atanazego polega nie tylko na nadaniu jej charakteru dogmatycznego, na co zwraca uwagę J. Królikowski ${ }^{36}$. Niewątpliwie Biskup Aleksandrii wprowadził nowy styl w refleksji mariologicznej, poszerzając ściśle biblijny charakter mariologii wcześniejszych Ojców. Bez wątpienia także stosowanie przez niego w sposób konsekwentny tytułu $\Theta \varepsilon$ eotóxos dla Maryi przygotowało i utorowało drogę obrony tego tytułu przed błędami nestorianizmu Cyrylowi Aleksandryjskiemu $^{37}$. Naszym zdaniem jednak, nie wyczerpuje się na tym nowość i oryginalność refleksji mariologicznej Atanazego, wyraża się ona bowiem także w nadaniu jego mariologii wymiaru antropologicznego; oznacza on poszerzenie przedmiotu mariologii. Biskup Aleksandrii nazywając Maryję „naszą siostrą" wytyczył nowy kierunek mariologii. Uzasadnia to wniosek, że dał on podstawy do wyartykułowania mariologii antropologicznej w dzisiejszym rozumieniu tego pojęcia. Słuszne także wydaje się przekonanie, że sformułowania mariologiczne Atanazego mogą być nadal inspirujące dla rozwoju tej dyscypliny teologicznej.

${ }^{34}$ Por. Ephrem Syrus, Carmen de Beata Maria Virgine, ed. Lamy I 2, 523-537, thum. W. Kania: Pieśn o Najświętszej Maryi Pannie, PSP 11, 30-32; Cyrillus Alexandrinus, Homilia IV. De Maria Deipara in Nestorium 4, PG 77, 992-996.

35 Ten element wydaje się ciągle słabo rozwinięty we współczesnej mariologii. Próbę ukazania mariologii jako dyskursu o człowieku podejmuje B. Ferdek (dz. cyt.). W tytule swego studium umieszcza nawet wyrażenie Atanazego: , nasza Siostra”. Niestety ogranicza się tylko do ogólnego wskazania, że pochodzi ono z Listu do Epikteta, nie podając szczegółowego miejsca, w którym się ono znajduje (zob. s. 13 i 139), ani też nie analizując kontekstu teologicznego, występującego w dziele Atanazego wyrażenia. Tym niemniej, samo opracowanie stanowi bez wątpienia oryginalny wkład do literatury mariologicznej.

${ }^{36}$ Por. Królikowski, Theotokos w teologii św. Atanazego, s. 68.

37 Tezę taką stawia także M. Starowieyski (Mariologia św. Atanazego Wielkiego, s. 130). 


\section{MARIE - NOTRE SOEUR}

Une contribution patristique à la mariologie anthropologique

\section{(Résumé)}

L'objet du présent article est l'analyse de la constatation d'Atanase „Marie est notre soeur", qui figure dans Epistula ad Epictetum 7. L'auteur analyse d'abord le contexte christologique de la constatation précitée. Afin de prouver la vraie nature humaine du Christ, il évoque la nature humaine de Marie en tant que sa Mère. Il développe ainsi l'idée de l'union étroite unissant Marie à tous les hommes, pour qui elle est comme une soeur. Cette union a sa source dans le fait que tous les hommes (y compris Marie) font partie de la progéniture d'Adam. L'auteur estime qu'Atanase peut être considéré comme précurseur de la mariologie anthropologique au sens que nous attribuons aujourd'hui à ce terme. 